\title{
Metode Pusat dan Circular Hough Transformation untuk Mendeteksi Lingkaran pada Sebuah Citra
}

\author{
Zaiful Bahri \\ Jurusan Ilmu Komputer Fakultas Matematika Dan Ilmu Pengetahuan Alam Universitas Riau \\ Jl. HR. Soebrantas Km. 12,5 Simpang Baru Panam, Pekanbaru, Riau, telp. 0761-63273 \\ e-mail: zaiful.bahri@lecturer.unri.ac.id
}

\begin{abstract}
Abstrak
Tulisan ini membahas tentang penerapan metode pusat dan Circular Hough Transformation(CHT) untuk mendeteksi semua lingkaran yang terkandung dalam citra baik lingkaran tunggal maupun lingkaran yang tumpang tindih. Metode pusat dan CHT memainkan peran penting dalam mendeteksi lingkaran yang terkandung dalam citra melalui array akumulator dua dimensi $A(a, b)$ yang memiliki memori berurutan dengan titik pusat dari lingkaran yang tumpang tindih sehingga dapat dihitung untuk setiap titik pada kurva menggunakan nilai parameter jari-jari yang dipilih untuk mendapatkan nilai triplet $(a, b, r)$ pada Circular Hough Transformation (CHT). Metode pusat merupakan alternatif lain untuk mendetekasi lingkaran dalam sebuah citra, melalui pre-processing seperti, input citra, deteksi objek, ambang batas tepi, skala abu-abu. Kemudian digunakan metode pusat untuk CHT. Akhirnya adalah mengimplementasikan metode pusat dan Cricular Hough Transformation menggunakan Matlab R2020b. Dengan sisitem yang dibangun dapat dideteksi seluruh lingkaran yang terdapat pada citra dengan akurasi $100 \%$ dengan memberikan intensitas cahaya 0.93 dan ambang batas 0.33 dan polarisasi objek gelap dan terang serta rentang jarijaroi antara 16px dan 110px. Tentunya ini tidak berlaku untuk citra yang memuat lingkaran dengan jari-jari yang lebih dari 110px atau kurang dari 16px.
\end{abstract}

Kata kunci: Metode Pusat, Lingkaran, Jari-Jari, Citra, CHT

\begin{abstract}
This paper discusses the application of the center method and Circular Hough Transformation (CHT) to detect all circles contained in an image, both single circles and overlapping circles. The center and CHT methods play an important role in detecting the circle contained in the image via a two-dimensional accumulator array $A(a, b)$ which has sequential memory with the center points of the overlapping circles so that it can be calculated for each point on the curve using parameter values. the radius selected to obtain the triplet values $(a, b, r)$ of the Circular Hough Transformation (CHT). The center method is another alternative for detecting circles in an image, through pre-processing such as image input, object detection, edge threshold, grayscale. Then the central method for CHT was used. Finally is to implement the central method and the Cricular Hough Transformation using the Matlab R2020b. With the built system it can be detected all the circles in the image with 100\% accuracy by providing a light intensity of 0.93 and a threshold of 0.33 and polarization of dark and light objects and a radius range between 16px and 110px. Of course this does not apply to images that contain circles with radii greater than 110px or less than 16px.
\end{abstract}

Keywords: Center Method, Circle, Radii, Image, CHT.

\section{Pendahuluan}

Perkembangan teknologi dan informasi dalam pengolahan citra sangat berkembang dan banyak peneliti ingin mengungkapkan berbagai alternatif lain untuk menguji atau mengimlementasikan metode atau algoritma dalam mendeteksi dan mengenali objek. Berbagai metode dan teknik digunakan untuk mendeteksi mulai dari paling sederhana, seperti garis, lingkaran, persegi, persegi empat, huruf, angka dan sampai dengan yang kompleks, seperti 
pengenalan pola plat nomor kendaraan dan lain sebagainya dalam suatu sistem baik menggunakan objek online maupun offline.

Citra adalah sekumpulan piksel yang mempunyai perbedaan nilai R(Red), G(Green) dan $\mathrm{B}$ (Blue). Hough Transformation menggunakan citra dengan warna grey(abu-abu) dan penggunaan setiap piksel untuk mendeteksi garis dan kurva pada persegi dan lingkaran [1]. Berbagai teknik digunakan untuk mendeteksi dan mengenali lingkaran dengan denominasi yang berbeda. Berbagai variasi teknik dan pendekatan seperti Circular Hough Transformation, Artificial Neural Network, Heuristics dan lain-lain bisa dilakukan untuk mendeteksi lingkaran.

Sistem deteksi juga banyak digunakan untuk penelitian oleh institusi atau organisasi yang bertujuan untuk mendapatkan hasil yang lebih baik dari penelitian sebelumnya. Ada tiga jenis sistem deteksi berdasarkan pada metode yang berbeda, sistem berbasis metode mekanik, sistem berbasis metode elektromagnetik dan sistem berbasis pemrosesan citra. Dalam tulisan ini digunakan metode yang ketiga untuk mendeteksi lingkaran-lingkaran yang terdapat dalam sebuah citra. dalam sistem deteksi lingkaran, mula-mula sebuah citra diambil umumnya menggunakan kamera atau scanner. Citra ini diproses menggunakan berbagai teknik atau metode pemrosesan citra seperti segmentasi [2-3], deteksi tepi [4], dan berbagai fitur ekstraksi ciri citra [5-7].

Pada penelitian [4] ada beberapa metode deteksi tepi lingkaran yang dapat digunakan untuk mendeteksi tepi dengan kelebihan dan kekurangannya. Di antaranya adalah metode Sobell, Robert, Prewitt, Canny [8] dan lain-lain. Dari hasil uji coba yang dilakukan [4] terhadap empat metode di atas, dapat diambil kesimpulan bahwa untuk mendeteksi tepi lingkaran (iris mata) yang terbaik adalah metode Sobell dengan 756 citra iris mata terdapat 20 citra tunggal yang terpilih secara random tidak dapat dideteksi atau sekitar $97,4 \%$ terdeteksi. Akurasi hasil penelitian[10] dalam mendeteksi lingkaran menggunakan metode CHT dan Ar.Drone Quadcopter adalah 85\%. Penelitian ini juga menggunakan objek lingkaran tunggal. Pada penelitian[9], dengan menggunakan Directional Gradient Method untuk CHT dapat dideteksi beberapa koin(lingkaran) tunggal dengan berbagai ukuran serta label dan warna yang berbeda, di mana semua koin dapat dideteksi dengan baik.

Dari beberapa penelitian dan hasilnya di atas terlihat jelas bahwa penelitian tersebut menggunakan objek lingkaran tunggal terpisah menggunakan algoritma CHT [11-15] dan belum ada yang mencapai keberhasilan 100\%. Dalam penelitian ini dilakukan untuk deteksi beberapa lingkaran tunggal terpisah maupun lingkaran tumpang tindih dengan mengambil polarisasi gelap dan terang. Di mana sistem deteksi ini menggunakan metode pusat untuk CHT yang merupakan suatu alternatif lain untuk dapat diterapkan dalam mendeteksi lingkaran baik lingkaran tunggal maupun lingkaran tumpang tindih. Tujuannya adalah untuk mengembangkan ilmu pengetahuan dan menerapkan ilmu matematika (algoritma metode pusat dan CHT) pada pengolahan citra dengan menerapkan persamaan $(x-a)^{2}+(y-$ $b)^{2}=r^{2}$ yang diubah ke dalam persamaan parametrik. Di mana dari persamaan parametrik ini diperoleh triplet $(a, b, r)$ yang merupakan dasar untuk mendeteksi lingkaran untuk metode pusat dan CHT. Tujuan lainnya adalah apakah metode pusat untuk CHT dapat mendeteksi beberapa lingkaran terpisah maupun lingkaran tumpang tindih pada suatu citra. Manfaatnya adalah untuk mengetahui kemampuan algoritma metode pusat untuk CHT dalam mendeteksi lingkaran dengan menghitung jumlah lingaran terdeteksi dibagi dengan jumlah seluruah lingaran di kali $100 \%$. Selain itu manfaatnya adalah dapat digunakan untuk mendeteksi koin yang tumpang tindih yang secara kasat mata koin tersebut tidak terlihat dengan jelas hanya beberapa tepi koin saja yang terlihat[14]. Terakhir adalah mengimplemntasikan algoritma metode pusat untuk CHT menggunakan Matlab R2020b.

\section{Metode Penelitian}

\subsection{Deteksi Lingkaran}

Dalam penelitian ini digunakan metode pusat untuk CHT untuk mendeteksi lingkaran dikarenakan metode ini menggunakan batasan dengan filtering intensitas cahaya yang didapat dari perubahan citra dari grayscale menjadi biner. Hough Transformation menggunakan citra 
dengan warna grey(abu-abu) dan setiap piksel digunakan untuk mendeteksi garis dan kurva pada persegi empat dan lingkaran.

\subsection{Segmentasi Citra}

Tujuan segmentasi adalah untuk menyederhanakan dan atau untuk merubah representasi suatu citra ke dalam sesuatu yang lebih berguna dan lebih mudah untuk dianalisa. Deteksi tepi merupakan suatu cara segmentasi yang paling ampuh, Proses deteksi tepi sangat penting sebagai informasi tepi yang diperlukan pada teknik Circular Hough Transformation. Berbagai metode deteksi tepi diterapkan untuk aplikasi yang berbeda.

\subsection{Definisi Hough Transformation}

Misalkan $f(X, P)$ adalah suatu fungsi himpunan yang terdiri dari $n$ variabel, $X=$ $\left\{x_{1}, x_{2}, \ldots, x_{n}\right\}$ dengan himpunan yang terdiri dari $m$ parameter $P=\left\{p_{1}, p_{2}, \ldots, p_{m}\right\}$. Di dalam aplikasi $\mathrm{X}$ adalah $(\mathrm{x}, \mathrm{y})$, di mana $\mathrm{X}$ dan $\mathrm{y}$ adalah koordinat suatu titik di dalam bidang sebuah citra, dan $\mathrm{P}$ adalah $(\mathrm{a}, \mathrm{b}, \mathrm{r})$, di mana $\mathrm{a}, \mathrm{b}$ dan $\mathrm{r}$ adalah pusat koordinat dan jari-jari sebuah lingkaran. Secara umum HT adalah sebuah transformasi yang memetakan fungsi $f(X, P)$ dalam variable ruang $X$ ke dalam $A(P)$ di dalam parameter ruang p:

$$
A(P)=H T(f(X, P))
$$

HT dapat diekspresikan atau diimplementasikan dengan fungsi transform:

$$
A(P)=H T(f(X, P))=\sum_{x} W(f(X, P), X, P)
$$

di mana $\mathrm{W}($.$) adalah fungsi kernel HT yang didefinisikan sebagai f(X, P)=0$ untuk suatu observasi $X$, maka $\mathrm{W}()=$.1 lainnya $\mathrm{W}()=$.0 . HT adalah suatu tool yang sangat berguna untuk menemukan suatu pola ke dalam sebuah citra seperti garis dan kurva. Dengan mentransformasikan satu titik ke dalam ruang parameter, Hough Trasnformation dengan mudah mengenal pola lokal.

\subsection{Array Accumulator}

Proses menemukan sebuah lingkaran dalam CHT adalah dengan cara, temukan semua tepi dalam citra, teknik yang digunakan bisa Canny, Sobel atau operasi Morphologi dan gradient direction. Pada setiap titik tepi yang ditemukan, gambar lingkaran-lingkaran dengan jari-jari tertentu. Lingkaran ini digambarkan dalam ruang parametrik, seperti sumbu $x$, adalah nilai $a$, dan $y$ adalah nilai $b$, sedangkan $z$ adalah jari-jari $r$. Pada koordinat yang memiliki perimeter gambar lingkaran, ditingkatkan nilainya dalam array accumulator yang esensialnya mempunyai ukuran yang sama seperti ruang parameter. Dengan cara ini setiap titik tepi bisa dikelilingi pada citra input lingkaran dengan jari-jari tertentu dan menaikan nilai array accumulator.

\subsection{Intensitas Cahaya}

Intensitas cahaya sangat dibutuhkan di dalam pengolahan citra, di mana intensitas cahaya ini dapat digunakan untuk memudahkan deteksi lingkaran dan juga diberikan polarisasi objek terang atau gelap sehingga deteksi lingkaran dengan polarisasi permukaan objek terang atau gelap dapat dilakukan dalam satu sistem.

\subsection{Circular Hough Transformation}

CHT memetakan setiap lingkaran:

$$
r^{2}=(a-x)^{2}+(b-y)^{2}
$$

Seperti terlihat pada persamaan (3), bahwa persamaan (3) mempunyai tiga buah parameter yaitu, a, b dan r. Di mana a, b adalah pusat lingkaran dan $r$ adalah jari-jari lingkaran. Persamaan (3) dapat diubah menjadi persamaan parametrik dengan bentuk:

$$
\begin{aligned}
& x=a+r \operatorname{Cos}(\theta) \\
& y=b+r \operatorname{Sin}(\theta)
\end{aligned}
$$

Jadi ruang parametrik sebuah lingkaran adalah $\mathrm{R}^{3}$ sedangkan garis hanya memilik ruang $\mathrm{R}^{2}$.

Jumlah parameter untuk lingkaran pada $\mathrm{R}^{3}$ meningkat. Oleh karena itu Hough Transformation secara umum memerlukan bentuk sederhana dengan memiliki $\mathrm{R}^{2}$ dan paling 
banyak $\mathrm{R}^{3}$. Untuk sederhananya, reperesentasi lingkaran dengan parametrik, jari-jarinya bisa sebagai suatu konstanta atau terbatas. Untuk lebih jelasnya dapat dilihat pada Gambar 1:

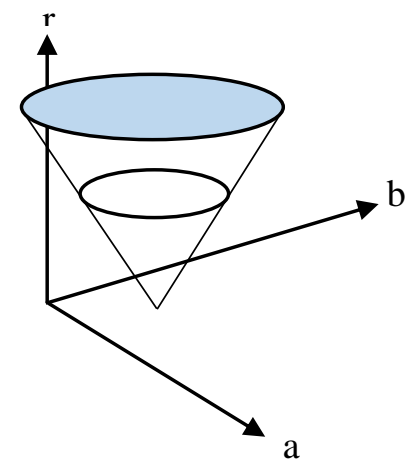

Gambar 1. Ruang parametrik untuk CHT

Untuk suatu perameter $(a, b, r)$ yang diberikan pada himpunan titik $\left\{\left(x_{j}, y_{j}\right)\right\}$ yang memenuhi persamaan lingkaran (1), semuanya harus terletak pada garis keliling yang didefinisikan oleh $(a, b, r)$. Sebaliknya, jika himpunan titik $\left\{\left(x_{j}, y_{j}\right)\right\}$ semuanya terletak pada garis lingkaran yang sama, maka harus memenuhi persamaan lingkaran (1) dengan parameter yang sama juga. Ini berarti bahwa dari himpunan parameter berhingga(triplet $)\left\{\left(a_{j}, b_{j}, r_{i j}\right)\right\}$ pada setiap titik $\left(x_{j}, y_{j}\right)$ dapat ditemukan himpunan parameter $(a, b, r)$ untuk himpunan titik $\left\{\left(x_{j}, y_{j}\right)\right\}$. Ini merupakan metode dasar yang dapat diimplementasikan pada CHT. Berikut adalah algoritma CHT.

Langkah 1. Set array accumulator (a, b, r) menjadi 0.

Langkah 2. Untuk setiap titik dalam himpunan $m$ pasangan parameter $\left(x_{j}, y_{j}\right)$ yang mungkin dipilih, dan himpunan parameter lain $\left(r_{i j}\right)$ dihitung dari persamaan (3).

$$
r_{i j}^{2}=\left(a_{j}-x_{i}\right)^{2}+\left(b_{j}-y_{i}\right)^{2}
$$

Untuk setiap titik $A\left(a_{j}, b_{j}, r_{i j}\right)$ ditemukan, kemudian tambahkan 1 yang berhubungan dengan array accumulator:

$$
A\left(a_{j}, b_{j}, r_{i j}\right)=A\left(a_{j}, b_{j}, r_{i j}\right)+1
$$

Langkah 3. Array accumulator $A(a, b, r)$ dicari untuk lokal maksimum, yang masingmasing menunjukkan sebuah busur lingkaran. Karenanya parameter lingkaran yang sedang dideteksi $\left(a_{k}, b_{k}, r_{k}\right)$ pada distribusi $A\left(a_{k}, b_{k}, r_{k}\right)$ memenuhi:

$$
A\left(a_{k}, b_{k}, r_{k}\right)=\max _{i} A\left(a_{j}, b_{j}, r_{j}\right)
$$

Apabila sebuah kurva dilengkapi oleh sebuah lingkaran kontribusi pada accumulator merupakan busur kecil dari lingkaran besar bisa menjadi busur besar dari lingkaran kecil. Oleh kartena itu accumulator harus dinormalkan sehingga lingkaran yang ditemukan sesuai. Normalisasi dapat dilakukan dengan mengalikan array accumulator $A(a, b, r)$ pada langkah 3 sebelumnya dengan faktor skala:

$$
S(x)=\frac{1}{2 \pi r}
$$

\subsection{Metode Pusat Untuk Circle Hough Transformation}

Metode Pusat sebuah accumulator dua dimensi $A(a, b)$ atau $A(P)$ adalah memori sequensial dengan empat komponen yang dihitung untuk setiap titik pada kurva menggunakan nilai parameter $r_{j}$ yang dipilih. Prosedur utama Metode Pusat untuk algoritma CHT adalah sebagai berikut: 
Langkah 1. Array Accumulator $A(a, b)$ diset menjadi 0

Langkah 2. Set $n$ titik pada kurva $\left(x_{i}, y_{i}\right)$

Langkah 3. Pilih nilai parameter $r_{j}$ dengan coba-coba

Langkah 4. Seperti terlihat pada gambar 2, untuk setiap titik pada kurva, gunakan nilai parameter $r_{j}$ yang dipilih, kemudian untuk setiap nilai $b_{k}$ yang mungkin, nilai yang berhubungan dengan $a_{k}$ dapat dicari dengan formula:

$$
a_{k}=x_{i} \pm \sqrt{r_{j}^{2}-\left(y_{i}-b_{k}\right)^{2}}
$$

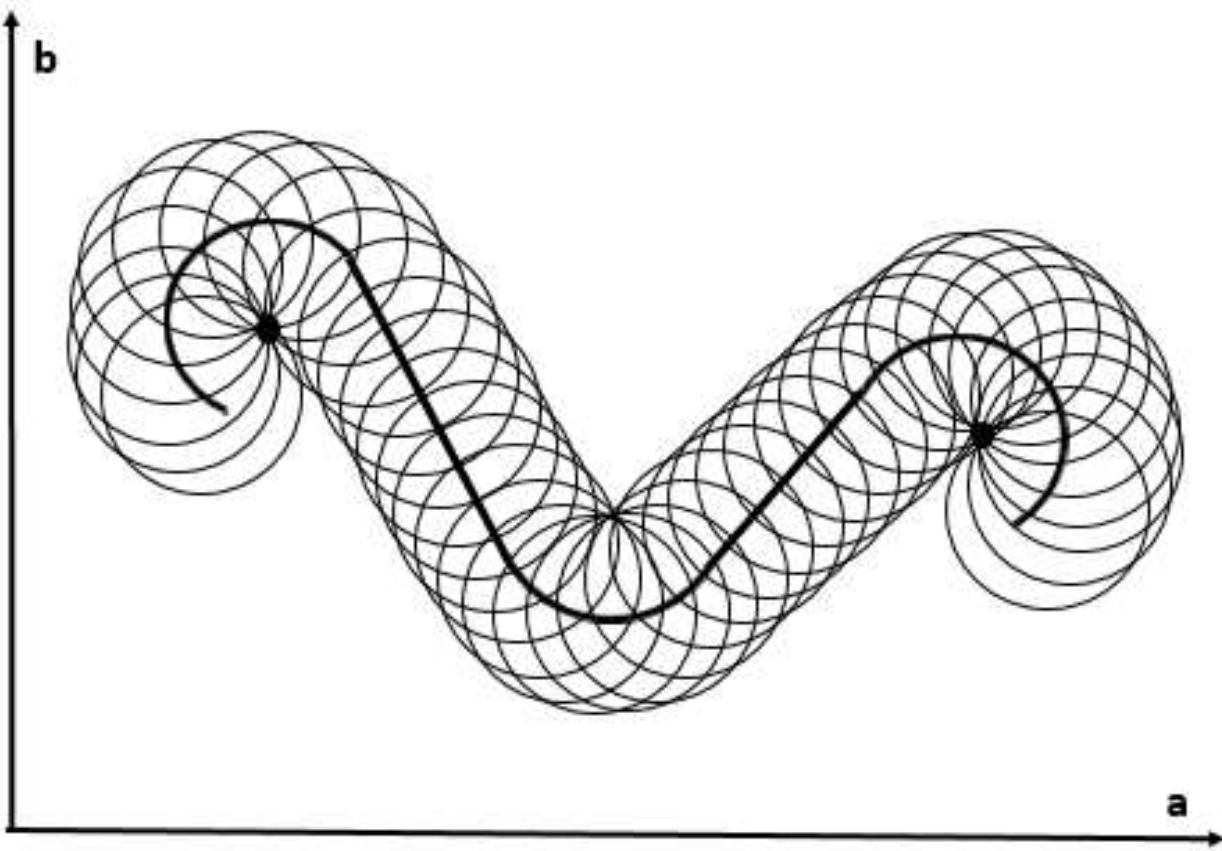

Gambar 2 Lokus pusat lingkaran dengan Metode Pusat jari-jari $r=r_{1}$

Ingat bahwa $\left(a_{k}, b_{k}\right)$ adalah suatu titik pusat lingkaran pada $\left(x_{i}, y_{i}\right)$. Untuk setiap pasangan nilai $\left(a_{k}, b_{k}\right)$, akumulator $A(a, b)$ ditingkatkan.

$$
A\left(a_{k}, b_{k}\right)=A\left(a_{k}, b_{k}\right)+1
$$

Langkah 5. Akumulator $A(a, b)$ ditreshold dengan fungsi $T(r)$.

$$
A\left(a_{k}, b_{k}\right)=\left\{\begin{aligned}
A\left(a_{k}, b_{k}\right), & \text { jika } A\left(a_{k}, b_{k}\right) \geq T\left(r_{j}\right) \\
0, & \text { yang lainnya }
\end{aligned}\right.
$$

Langkah 6. Akumlator array $A(a, b)$ dicari untuk local maksimum dan berhubungan dengan $a_{j}, b_{j}, r_{j}$, dan nilai nilai dalam akumulator array $A\left(a_{j}, b_{j}\right)$ disimpan di dalam memori sekuensial.

Langkah 7. Akumulator array diset kembali menjadi 0 , parameter $r_{j}$ diupdate, dan algoritma diresume dari langkah 4 untuk semua kemungkinan parameter $r$.

Langkah 8. Daftar parameter $(a, b, r)$ mencari sendiri untuk lokal maksimum.

Intinya adalah setelah diperoleh pusat lingkaran menggunakan Metode Pusat, kemudian dicari jari-jari lingkaran. Dengan ditemukannya sebuah lingkaran dengan jari-jarinya kemudian dilakukan transformasi menggunakan $\mathrm{CHT}$ untuk seluruh lingkaran yang ada pada citra tersebut untuk mendapatkan triplet $\left(\left(a_{j}, b_{j}, r_{i j}\right)\right.$. 


\section{Hasil dan Pembahasan}

\subsection{Input Citra Lingkaran}

Input citra lingkaran adalah citra yang diambil menggunakan kamera atau citra yang diambil melalui internet. Dalam penelitian ini citra input lingkaran secara offline, di mana citra lingkaran disimpan di dalam komputer. Untuk mempercepat proses, maka citra lingkaran disimpan dalam bentuk citra grayscale (skala abu-abu). Gambar $\mathbf{3}$ adalah input citra lingkaran:

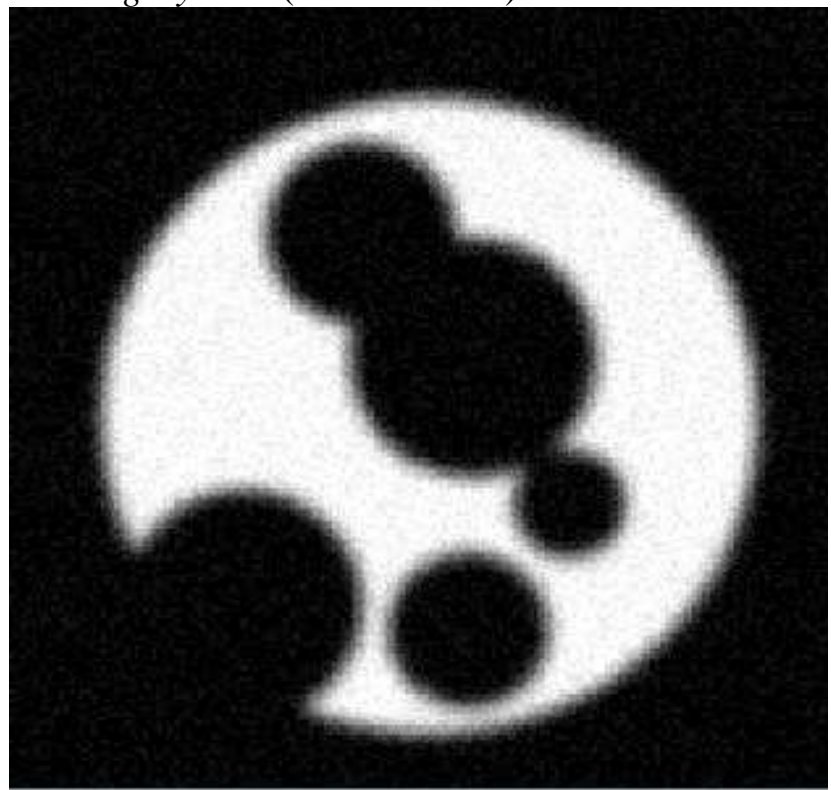

Gambar 3 Input Citra Lingkaran

\subsection{Pemberian Intensitas Cahaya}

Intensitas cahaya citra lingkaran diperlukan untuk mendapakat kemudahan deteksi setiap lingkaran, di mana rentang intensitas cahaya citra adalah dari 0 sampai 1 dan juga diberikan polaritas objek gelap dan terang sehingga lingkaran yang terdeteksi adalah lingkaran berwarna latar depan gelap dan terang.bida dilihat pada gambar 4 dan 5

\subsection{Deteksi Tepi dan Ambang Batas Citra Lingkaran}

Proses deteksi dan pemberian ambang batas citra lingkaran sangat diperlukan untuk mendeteksi masing-masing lingkaran. Dengan diperolehnya deteksi dan pemberian ambang batas masing-masing lingkaran sehingga dapat ditentukan jari-jari masing-masing lingkaran menggunakan metode pusat untuk Circular Hough Transformation. Ambang batas yang digunakan dalam penelitian ini pada rentang 0 sampai dengan 1. Pengambilan nilai ambang batas ini sangat diperlukan untuk menentukan ketepatan jari-jari lingkaran. Semakin kecil nilai ambang batas, maka semakin akurat jari-jari lingkaran yang dideteksi dan sebaliknya.

Dapat dilihat bahwa deteksi dan pemberian ambang batas lingkaran dilakukan untuk lingkaran grayscale. Gambar 6 merupakan gambar deteksi dan pemberian ambang batas untuk setiap ligkaran yang terdapat di dalam citra grayscale. Nilai untuk ambang batas tepi lingkaran ini diambil antara 0 dan 1. Bila rentang yang diambil sampai dengan 1 dikhawatirkan jari-jari lingkaran yang terdeteksi akan semakin besar dari nilai jari-jari yang sebenarnya. Untuk itu perlu dipertimbangkan mengambil nilai ambang batas tepi lingkaran sekecil mungkin agar perhitungan jari-jari linngkaran lebih akurat.

Nilai minimal jari-jari lingkaran yang diambil dalam penelitian adalah 16 dan nilai jari-jari maksimal adalah 110. Jika nilai minimal diambil mulai dari 0 sampai dengan 110, maka proses untuk mendeteksi lingkaran akan mengambil waktu yang lumayan lama. Apa lagi jika rentang nilai jari-jari dibuat semakin besar maka waktu untuk proses deteksi lingkaran juga semakin lama. Nilai maksimal jari-jari lingkaran pada suatu citra dapat diambil dari nilai minimal ukuran panjang atau lebar citra. 
Proses deteksi lingkaran yang paling penting di dalam tulisan ini adalah proses pemberian intensitas cahaya. Dimana intensitas cahaya yang di ambil adalah 0,93. Apa bila nilai intensitas cahaya yang diambil lebih dari 0,93 sampai dengan 1 , maka deteksi lingkaran tidak dapat dilakukan, ini disebablan terjadinya polarisa cahaya. Begitu juga jika nilai inatensitas cahaya yang diberikan kurang dari 0,93, maka ada beberapa lingkaran yang tidak terdeteksi.

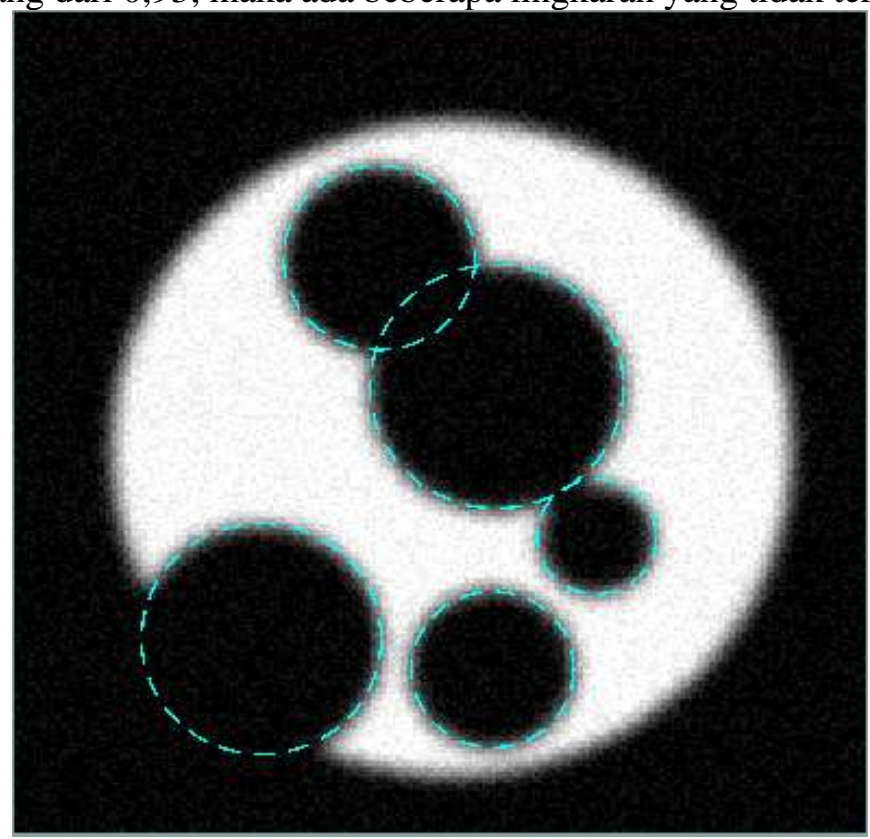

Gambar 4 Pemberian Intensitas Cahaya Dengan Permukan Gelap

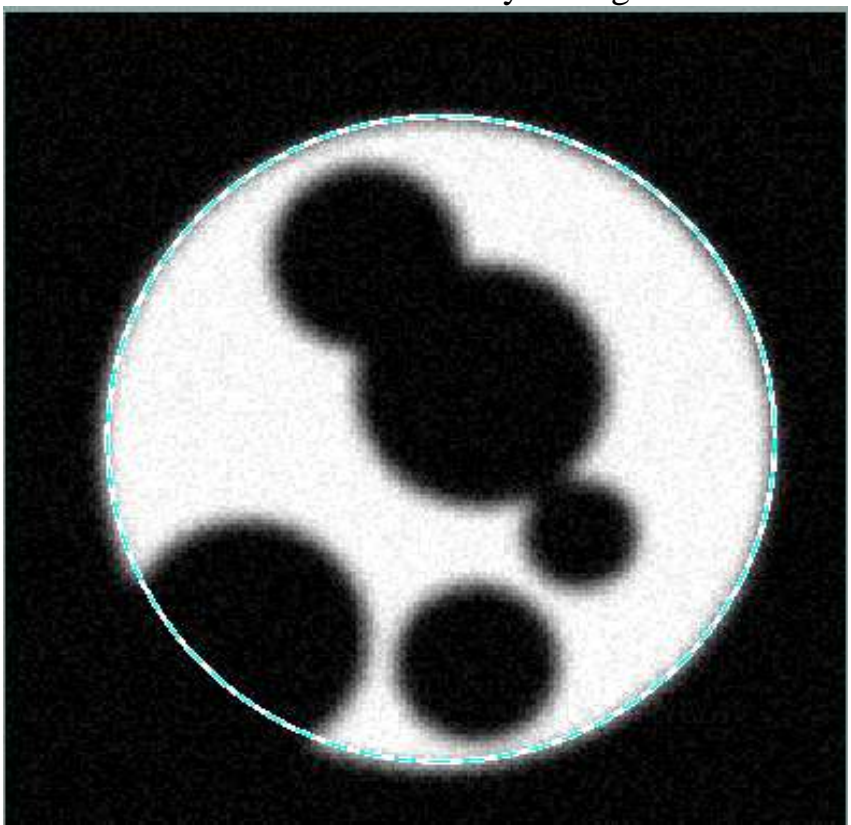

Gambar 5 Pemberian Intensitas Cahaya Dengan Permukaan Terang

\subsection{Hasil Deteksi}

Dari hasil dan pembahasan terlihat bahwa dengan menggunakan metode pusat untuk Circular Hough Transformation permasalahan deteksi lngkaran dapat dilakukan dengan beberapa proses yang harus dilakukan sebelumnya. Proses-proses tersebut merupakan proses pendukung terhadap deteksi lingkaran. Hasil proses deteksi lingkaran dapat dilihat mulai dari gambar 3 sampai dengan gambar 6. Di mana hasil deteksi terhadap sebuah citra yang di dalamnya terdapat 6 buah gambar lingkaran tumpang-tindih dengan permukaan galap dan 
terang yang tidak terdapat pada penelitian lain berhasil dideteksi $100 \%$. Ini menunjukkan bahwa hasil penelitian sedikit lebih baik dari hasil[4] dan jauh lebih baik dibandingkan dengan hasil penelitian[9]. Hasil tersebut dilakukan menggunakan metode pusat untuk CHT dengan tingkat intensitas cahaya 0.93 , ambang batas 0.33 dan jari-jari minimum 16px dan maksimum 110px. Hasil lengkap deteksi lingkaran dapat dilihat pada tabel 1.

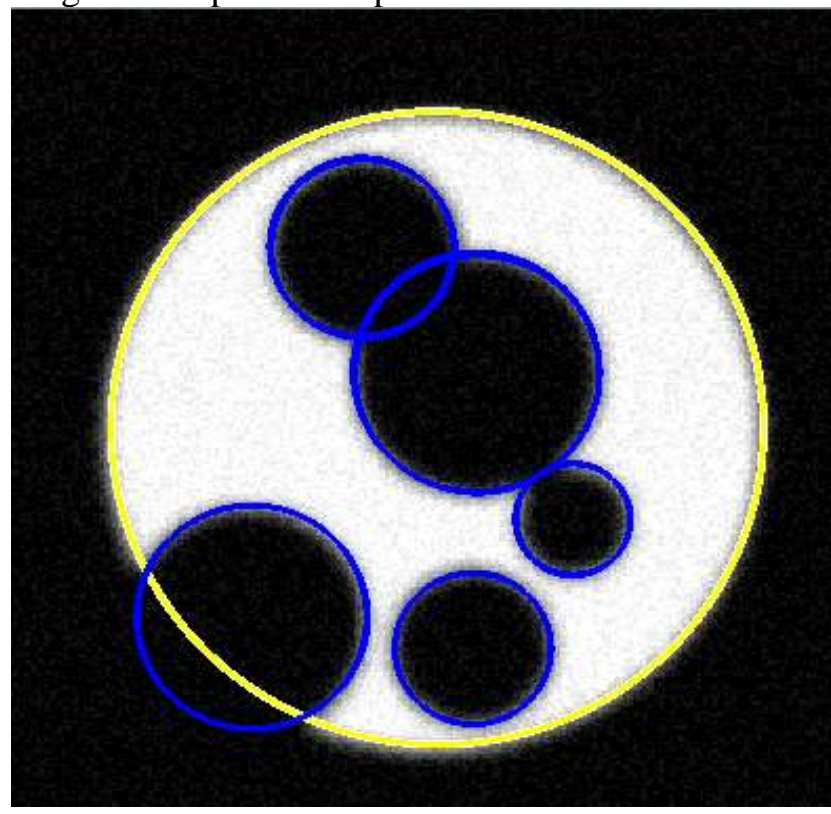

Gambar 6 Deteksi Tepi Lingkaran

Tabel 1. Hasil Deteksi Lingkaran Dengan Intensitas Cahaya 0.93 dan Ambang Batas 0.33 dan jari-jari minimum 16px dan maksimum 110px.

\begin{tabular}{ccccccc}
\hline \multirow{2}{*}{ No. Lingkaran } & $\begin{array}{c}\text { Intensitas } \\
\text { Cahaya }\end{array}$ & $\begin{array}{c}\text { Ambang } \\
\text { Batas }\end{array}$ & \multicolumn{2}{c}{ Titik Pusat Lingkaran } & Radius & \multirow{2}{*}{$\begin{array}{c}\text { Polarisasi } \\
\text { Objek }\end{array}$} \\
\cline { 4 - 5 } & & & 144.52 & 205.49 & 24.50 & Gelap \\
\cline { 4 - 5 } & & & 176.43 & 164.90 & 16.59 & Gelap \\
2 & & & 110.59 & 76.98 & 28.77 & Gelap \\
3 & 0.93 & 0.33 & 146.11 & 117.45 & 38.01 & Gelap \\
4 & & & 75.17 & 195.41 & 35.72 & Gelap \\
5 & & & 132.72 & 136.02 & 101.68 & Terang \\
6 & & & & & & \\
\hline
\end{tabular}

\section{Kesimpulan}

Berdasarkan hasil dan pembahasan dapat diambil kesimpulan bahwa sistem yang dibangun dapat mendeteksi lingkaran tunggal dan tumpang tindih dengan akurasi intensitas cahaya 0.93 dan ambang batas 0.33. Lingkaran yang terdeteksi ada enam dengan polarisasi permukaan gelap 5 dan terang 1 . Semua lingkaran yang terdeteksi dapat ditentukan titik-titik pusat dan panjang jari-jari untuk setiap lingkaran. Namun demikin pemilihan intensitas cahaya 0.93 dan ambang batas 0.33 serta rentang jari-jari 16px dan 110px belum tentu dapat digunakan pada citra yang lain. Ke depannya metode pusat untuk CHT ini dapat dikembangkan untuk mendeteksi koin Indonesia tunggal maupun yang tumpang tindih. Dan juga dapat digunakan untuk mendeteksi pola objek lingkaran, seperti mata, roda, cincin dan lain sebagainya.

\section{Ucapan Terima Kasih}

Terima kasih diucapkan kepada Dekan FMIPA Universitas Riau yang telah menyediakan hibah dana penelitian dan pengabdian kepada masyarakat tahun 2019. Terima kasih juga saya 
sampaikan kepada teman sejawat yang berkecimpung di dalam penelitian pengolahan citra di jurusan Ilmu Komputer atas masukan-masukannya. Terakhir, saya berharap untuk ke depannya Dekan FMIPA Universitas Riau dapat meningkatkan jumlah pendanaan baik untuk penelitian maupun pengabdian kepada masyarakat.

\section{Daftar Pustaka}

[1] W.O. Barbosa dan A.W. Viera. "On the Improvement of Multiple Circles Detection from Images using Hough Transform, "Tendencias em Matematica Aplicada e Computacional, Vol. 20, N. 2, pp. 331-342, 2019.

[2] R. Priyadharsini, A. Beulah and T. Sree Sharmila."Optic disc and cup segmentation in fundus retinal images using feature detection and morphological techniques," CURRENT SCIENCE, VOL. 115, NO. 4, pp. 752, 2018.

[3] Orisa, Mira dan Hidayat, Taufik. " Analisis Teknik Segmentasi Pada Pengolahan Citra," Jurnal MNEMONIC Vol 2, No. 2, pp. 9-13, 2019.

[4] Amalia, Ayu F. dan Saputro, Handoyo. "Analisis Deteksi Iris Mata Menggunakan Metode Deteksi Tepi Sobel," Jurnal Science Tech Vol. 4, No. 1, pp. 9-13, 2018.

[5] Ningrum, Maisura dan Fadillah, Nurul. "Deteksi Pengenalan Pola Lingkaran Menggunakan Metode Ekstraksi Ciri Citra Pada Parameter Metric, " Jurnal SIFO Mikroskil, Vol 19, No 2, pp. 57-67, 2018

[6] Rahman, Sayuti dan Dafitri, Haida "Aplikasi Simulasi Deteksi Lokasi Parkir Kosong Menggunakan Ektraksi Ciri Objek," Infotekjar : Jurnal Nasional Informatika Dan Teknologi Jaringan, Vol. 4 No. 1, pp. 99-104, 2019.

[7] Nugroho, Hendro. "Deteksi Citra Objek Lingaran Dengan Menggunakan Metode Ekstraksi Bentuk Circularity”, Integer Journal, Vol 2, No 1, pp. 54-59, 2017.

[8] Kirana, M. Chandra, Sartikha dan Erminawati, Ela,“ Penerapan Metode Canny Dalam Koreksi Lembar Jawaban Komputer Untuk Try Out”, Prosiding SENTIA 2017, Politeknik Negeri Malang Vol. 9, pp. 331-342, 2017.

[9] Bahri, Zaiful. "Implementasi Algoritma Circular Hough Transformation (CHT) Untuk Mendeteksi Multi Koin Indonesia Dengan Metode Gradient Direction," Prosiding Konferensi Nasional Matematika XIX, Vol. No. Pp.225-233, 1998.

[10] M. T. B. Zulfikar Ardi, G. E. Setyawan dan Utaminingrum, Fitri. " Implementasi Algoritma Hough Transform Pada Object Following Menggunakan Ar.Drone Quadcopter," Jurnal Pengembangan Teknologi Informasi dan Ilmu Komputer e-ISSN: 2548-964X Vol. 4, No. 1, pp. 134-141, 2020.

[11] Winata, Eflin, Risna, Helvi dan Angreni, Renni. “ Identifikasi Jenis Bangun Datar dengan Algoritma Line Hough Transform dan Circular Hough Transform,"Jatisi, Vol. 2 No. 2 pp. 120-129, 2016.

[12] Mahendhy N. Nassar, Nasrun, M. dan Latuconsina, Roswan. “ Detektor Kebohongan Dengan Analisis Pembesaran Diameter Pupil Dan Pergerakan Mata Menggunakan Metode Jaringan Syaraf Tiruan HopField Net," e-Proceeding of Engineering, Vol.5, No.3, pp. 46$55,2018$.

[13] Hermawati, Bhakti Yudho Suprapto, Andi Pranata, dan Firmansyah. " Purwarupa Pembersih Pipa Otomatis (Automatic Tube Remover) Pada Heat Exchanger Menggunakan Teknik Pengolahan Citra," Jurnal Rekayasa Elektrika, Vol. 11, No. 4, pp. 135-143, 2015

[14] Bahri, Zaiful dan Risanto, Joko. “ Implementation of Circular Hough Transformation Algorithm To Detect and Recognize Overlapped Indonesian Coins," International Journal of Science and Applied Technology, Vol. 3, No.2, pp. 52-59, 2018. 
[15] Jingkun Liu, Qi Fan. “ An Improved Randomized Circle Detection Algorithm Using in Printed Circuit Board Locating Mark," Applied Mathematics, Vol. 10, No. 10, pp. 1-6, 2019.

\section{(c) (1) (2)}

Digital Zone: Jurnal Teknologi Informasi dan Komunikasi is licensed under a Creative Commons Attribution International (CC BY-SA 4.0) 